(2) institute of development studies

Working Paper

Volume 2021 Number 558

Informal Workers and the State: The Politics of Connection and Disconnection During a Global Pandemic

Max Gallien and Vanessa van den Boogaard

November 2021 
The Institute of Development Studies (IDS) delivers world-class research, learning and teaching that transforms the knowledge, action and leadership needed for more equitable and sustainable development globally.

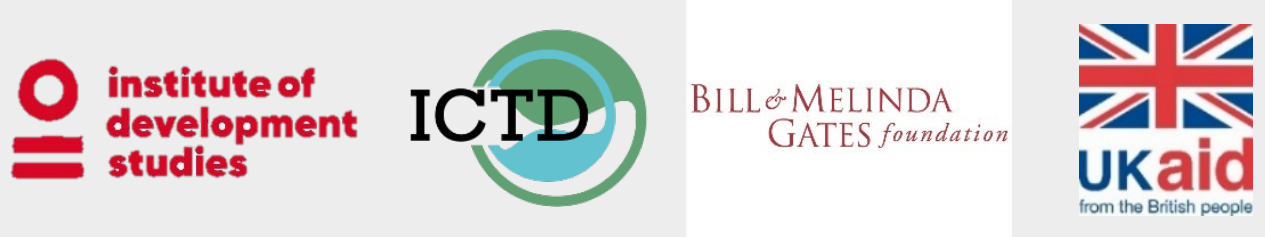

(C) Institute of Development Studies 2021

Working Paper Volume 2021 Number 558

Informal Workers and the State: The Politics of Connection and Disconnection During a Global Pandemic Max Gallien and Vanessa van den Boogaard

November 2021

First published by the Institute of Development Studies in November 2021

ISSN: 2040-0209 ISBN: 978-1-78118-897-2

DOI: $10.19088 / I D S .2021 .066$

Suggested citation: Gallien, M. and van den Boogaard, V. (2021) Informal Workers and the State: The Politics of Connection and Disconnection During a Global Pandemic, IDS Working Paper 558, Brighton: Institute of Development Studies, DOI: 10.19088/IDS.2021.066

A catalogue record for this publication is available from the British Library

This paper is funded by Bill \& Melinda Gates Foundation and UK aid from the UK government (Foreign, Commonwealth \& Development Office - FCDO, formerly DFID). The opinions are the authors' and do not necessarily reflect the views or policies of IDS, Bill \& Melinda Gates Foundation, or the UK government.

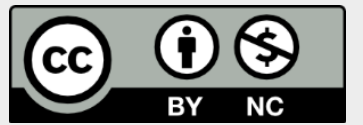

This is an Open Access issue distributed under the terms of the Creative Commons Attribution Non Commercial 4.0 International licence (CC BY-NC), which permits use, distribution and reproduction in any medium, provided the original authors and source are credited, any modifications or adaptations are indicated, and the work is not used for commercial purposes.

Available from:

Institute of Development Studies, Library Road

Brighton, BN1 9RE, United Kingdom

+44 (0)1273915637

ids.ac.uk

IDS is a charitable company limited by guarantee and registered in England

Charity Registration Number 306371

Charitable Company Number 877338 
Working Paper

Volume 2021 Number 558

Informal Workers and the State: The Politics of Connection and Disconnection During a Global Pandemic

Max Gallien and Vanessa van den Boogaard

November 2021 


\title{
Informal Workers and the State: The Politics of Connection and Disconnection During a Global Pandemic
}

\author{
Max Gallien and Vanessa van den Boogaard \\ November 2021
}

\section{Summary}

In low- and middle-income countries, informal workers are particularly vulnerable to the health and economic effects of the Covid-19 pandemic and often neglected by policy responses. At the same time, the crisis is rapidly changing the ways that states engage with informal workers. We argue that the relationships between informal workers and states - and the politics of creating and accessing these linkages - are a critical and frequently overlooked part of the politics of the pandemic. Both pre-existing structural disconnection from the state-embodied, for example, through limited access to health infrastructureand state attempts to build new connections, including through cash transfer programmes for informal workers, have a profound impact on the effectiveness and reach of state crisis responses. Without considering the varied and dynamic nature of the linkages between states and informal workers we cannot understand the heterogeneous health and economic impacts of the pandemic, state capacity to respond to the crisis, or institutional change in the context of crisis.

\section{Keywords}

Informality; informal economy; Covid-19; informal taxation; social protection; crisis responses 


\section{Authors}

Max Gallien is a political scientist specialising in the politics of informal and illegal economies, the political economy of development and the modern politics of the Middle East and North Africa. Max is an IDS Research Fellow in the Governance Cluster and with the International Centre for Taxation and Development (ICTD) where he leads the research programme on informality and taxation with Vanessa van den Boogaard, as well as the ICTD's capacity building programme.

Vanessa van den Boogaard is a Research Fellow at the International Centre for Tax and Development (ICTD), where she co-leads the research programme on informality and taxation and leads the programme on taxation and civil society. 


\section{Executive summary}

Informal workers make up over 60 per cent of the global labour force and more than 80 per cent in sub-Saharan Africa and South Asia (ILO 2018). In low- and middle-income countries, they have been particularly vulnerable to the effects of the Covid-19 pandemic. This has been in part due to unsafe work environments, limited capacity to adjust workspaces to comply with public health measures, constraints to accessing public health care, and embeddedness in global trade networks that have been affected by the pandemic. Critically, key determinants of informal workers' vulnerability relate to their relationship_or lack thereof-with state structures. The nature of pre-existing disconnection between the state and informal workers has shaped the design and effectiveness of many state responses to the crisis, with informal workers excluded from common forms of state-driven relief programmes, wage furlough schemes, or tax delays.

Exclusion, however, is only a part of the story. While informality is commonly conceptualised in opposition to the state, some connections between informal workers and the state have long existed, including through municipal registers for street-vendors or social protection programmes aimed at informal workers. Critically, these points of connection vary between countries, regions, and between different groups within the informal economy. By examining the effect of the pandemic on informal workers and their relationship with the state, we show how state responses to the crisis have been shaped by pre-existing relationships with different economic groups in society.

Meanwhile, early indications suggest that the crisis is shifting the politics of the state's relationship with informal workers, with institutional changes that may positively or negatively affect longer-term outcomes for informal workers. In some cases, states have targeted new relief and social protection programmes at informal workers. In other cases, states have renewed efforts to 'control' informality through, for instance, the demolition of unregulated market spaces, ostensibly justified by concerns about hygiene and safety. As states seek to find new ways to finance the recovery, extracting revenue from informal economies is increasingly discussed as a policy priority. At the same time, some groups of informal workers have new incentives to engage in collective action in order to make demands of the state, with growing expectations of the state's responsibility to provide essential services, particularly around health care and sanitation. These bargaining dynamics reflect shifting notions of the rights of citizenship and what the state owes both citizens and migrant workers.

Interconnections between the state and informal workers will continue to be formed and restructured in the post-crisis context, with consequences for statesociety and state-business relationships that far outlast this pandemic. This 
paper argues that neither the impacts of the crisis nor state capacity to respond to the crisis can be understood without understanding the changing nature of the relationships between the state and informal workers. In particular, we cannot understand heterogeneous crisis outcomes and the nature of social and political inclusion and exclusion without exploring the varied and dynamic nature of the interconnections between the state and informal workers, and the related politics of connection and disconnection. 


\title{
Contents
}

\author{
Acknowledgements
}

1. Introduction

2. Informal workers and the politics of disconnection

1.1 Lack of access to health care

1.2 Exclusion from social protection and reliance on informal social welfare

1.3 Inaccessible crisis relief

3. The new politics of connection: Crisis and institutional change

3.1 Crisis Relief: New intersections, old exclusions

3.2 Connection, taxation, and control

3.3 Non-state intermediaries, co-production and labour organization 24

4. Informality and the politics of the pandemic

5. Conclusions: The state, informal workers, and the long shadow of the pandemic 


\section{Acknowledgements}

The authors would like to thank Harshita Sinha, Soukayna Remmal and Ruvimbo Chidziva for their support in developing this paper, as well as Armin von Schiller for his comments on a previous version of this paper and Ruby Utting for her administrative support at IDS. We would also like to thank the organiser and participants of the panel on The Precarious New Deal: Inclusive Development and Precarious Workers at the Development Studies Association annual meeting in 2021. The project has been supported through funding by the International Centre for Tax and Development (ICTD). 


\section{Introduction}

As Covid-19 intensified across the globe in early 2020, much scholarship drew attention to variation in the health and economic effects across countries and demographic groups, policy choices, and state capacity to respond to the crisis. To fully understand variation in outcomes and state responses in low and middle income countries, we argue that it is necessary to consider the multi-faceted relationships between the state and informal workers, who make up over 60 per cent of the global labour force and more than 80 per cent in sub-Saharan Africa and South Asia (ILO 2018). ${ }^{1}$ Informal workers are especially vulnerable to the health and economic effects of the crisis, with almost 1.6 billion informal workers globally affected by lockdown and containment measures and/or working in the sectors hit hardest by the pandemic (ILO 2020d, e, f; Schotte et al. 2021; Daniel et al. 2020), yet have often been neglected by policy responses (Rateng 2020a). Focusing on the impacts of the crisis on informal workers enables us to see how states' capacity to address the crisis has been shaped by pre-existing relationships with different economic groups in society, with the politics of connection and disconnection shaping heterogeneous crisis outcomes.

Key determinants of informal workers' vulnerability in the context of the crisis relate to their relationship - or lack thereof - with state structures. The nature of pre-existing disconnection between the state and informal workers, with informal workers excluded from formal regulatory structures and workers' benefits, has shaped the design and effectiveness of many state-driven relief programmes. Indeed, informal workers have been excluded from common forms of statedriven relief programmes, including furlough schemes or the provision of personal protective equipment.

While this disconnection is important to understanding heterogeneous outcomes, the politics of exclusion is only part of the story of the multi-faceted and varied relationships that informal workers have with the state. While informality is commonly conceptualised in opposition to the state, connections between informal workers and the state have long existed, though they are unevenly distributed and often contested. ${ }^{2}$ Interconnections between informal workers and

\footnotetext{
We take a broad conception of informal work, including both rural and urban informality, informal work in both the formal and informal sector, as well as informal own-account workers. We follow the International Labour Organization's (ILO) definition of informal employment as 'all remunerative work (i.e., both self-employment and wage employment) that is not registered, regulated or protected by existing legal or regulatory frameworks, as well as non-remunerative work undertaken in an incomeproducing enterprise. Informal workers do not have secure employment contracts, workers' benefits, social protection, or workers' representation' (ILO 2020c).

2 This is in line with a growing body of literature dispelling simplistic views of the relationship between the state and the informal economy (see e.g., Chen and Carré 2020, Meagher and Lindell 2012, Meagher 2010).
} 
the state reflect varied modes of interaction, including the communication and enforcement of regulation, including through meetings between labour inspectors and the heads of informal associations; the payment of taxes, licences, or fees; registration for state programmes or authorisations, such as through municipal registers for street-vendors; the transfer of information; accessing public services and social welfare, including through social protection programmes aimed at informal workers; and processes of negotiation and bargaining.

Where they exist, interconnections between the state and informal workers are often more limited than state links with formal sector workers or enterprises, mediated through, for example, chambers of commerce, formal tax arrangements or employment-based social security schemes. As a result, most policy solutions aimed at improving informal livelihoods have focused on restructuring the relationship between the state and the informal economy. For instance, taxpayer registration drives are often motivated by benefits for both the state and informal workers thought to be associated with an institutionalised relationship (Gallien et al. 2021; Gallien and van den Boogaard 2021, forthcoming). Other strategies grant greater importance to the agency of informal workers and the need for bottom-up accountability to keep the state in check, often aiming to encourage informal labour organisation as a means of making collective demands of the state. ${ }^{3}$ While approaching the 'problem' of informality from different perspectives, both types of strategies effectively assume that the economic and political outcomes of informal workers are shaped by the nature of their interconnections with the state.

While the politics of building, seeking, or avoiding such interconnections between states and informal economies pre-dates the current global pandemic, early indications suggest that the crisis is shifting the politics of the state's relationship with informal workers, often in divergent directions, with institutional changes that may positively or negatively affect longer-term outcomes for informal workers. These politics have been shaped by shifting narratives about informality in divergent directions, either recognising the 'essential' nature of informal work or further stigmatising it as unhygienic and, thus, dangerous to the broader public. In some cases, states have introduced new relief and social protection programmes targeted explicitly to informal workers, underpinned by increasing recognition of the 'essential' nature of informal work. In other cases, by contrast, states have renewed efforts to 'control' informality through, for instance, the demolition of unregulated market spaces. While such strategies of control are not new, they have been underpinned by novel vigour, with states motivated, at least

For examples of collective organising within the informal economy, see the work of groups such as Women in Informal Employment: Globalizing and Organizing (WIEGO), India's Self Employed Women's Association (SEWA), or Homenet; for efforts to connect informal workers more effectively with formal trade unions, see The Friedrich Ebert Foundation's recent partnerships with the International Labour Organization (ILO) in Africa. For a theoretical discussion of these dynamics see Lindell (2010). 
ostensibly, by concerns about hygiene and safety that are especially salient in the context of the pandemic. Meanwhile, fiscal pressures facing states have led to increased policy attention to taxing the informal economy as a means of filling fiscal gaps. The variety and divergent nature of new interconnections between the state and informal workers makes clear that these points of interaction are not necessarily unidirectional or limited to a single use, while they can transform significantly over time. Underpinned by these discursive and fiscal dynamics, the intersections between states and informal workers will continue to be formed and restructured in the post-crisis context.

While state responses to informal workers often receive greater attention, informal workers have also been leading efforts to shift the nature of their relationships with the state. Often facing unprecedented challenges, some groups of informal workers have had new incentives to engage in collective action in order to make demands of the state. These efforts are underpinned by growing expectations of the state's responsibility to provide essential services, particularly around health care and sanitation and shifting notions of what the state owes both citizens and migrant workers.

Fuelled by the state and informal workers alike, the crisis has significantly shaped the relationships and points of interconnection between the state and informal workers. The pandemic has been 'generative of political subjectivities that reveal important shifts in the... relations between state and society' (Chigudu 2019: 413), though, as we will explore below, with significant variation across sub-populations in the informal economy - particularly with regard to women and informal migrant workers. ${ }^{4}$ Accordingly, we argue that neither the crisis nor the nature of state capacity in the crisis response can be understood without understanding the changing nature of the interconnections between the state and informal workers. In particular, we cannot understand heterogeneity without exploring the varied and dynamic nature of the relationship between the state and informal workers and the related politics of connection and disconnection. ${ }^{5}$ Our analysis of the changing politics of informality contributes to an examination of the pandemic that considers both its wider structural political

4 The vulnerability and experience of informal workers during the Covid-19 pandemic has been highly heterogeneous, reflecting the diversity of the sector itself. While informal workers as a broader group have been particularly vulnerable to the economic and health challenges of the pandemic, there remains huge variation in the actual lived experiences of informal workers. Notably, informal work frequently overlaps with other forms of economic, political, and geographic marginality, which can further exacerbate the hardship of informal workers. This is in line with scholars of critical medical anthropology, who recognize that social relations and structural power dynamics shape the nature, intensity, and distribution of viral infections and diseases within society (see e.g., Young 1982; Hamdy 2008).

5 This is in line with theoretical approaches that make clear that the interaction and blurred lines between formal and informal institutions is critical to understanding institutional outcomes (see e.g., Helmke and Levitsky 2004; Meagher 2007; Gallien 2020), as well as those that emphasize that the state is a product of the incorporation and appropriation of existing social forces (e.g., Migdal 2001). 
economy and its more unruly 'complexity, uncertainty, contingency and contextspecificity' (Leach et al. 2021).

The remainder of the paper is structured as follows. The second section outlines the politics and outcomes of the pre-existing disconnection of informal workers from the state, discussing the implications of informal workers lacking access to public health care and social welfare programmes during a global pandemic, while being excluded from the most prevalent forms of crisis relief. The third section highlights the ways in which the crisis is serving as a catalyst for institutional change in the relationships between the state and informal workers what we describe as the new politics of connection. Emphasising the heterogeneous dynamics across and between demographic groups, we explore the ways in which the intersections between the state and the informal economy are being shaped by the politics of the pandemic, simultaneously prompting new forms of inclusion, and reinforcing old patterns of exclusion. The fourth section reflects on how more focused exploration of the nature and effectiveness of states' interactions with the informal economy can better inform our understanding of both the impacts of the crisis and the reach and effectiveness of state institutions. The final section concludes and highlights key avenues for future research. 


\section{Informal workers and the politics of disconnection}

Informal workers largely lack many of the institutional relationships that the state has with formal workers, including through labour regulatory institutions, workmandated social protection schemes, and business and tax registers. ${ }^{6}$ Part of this disconnection is definitional - we often classify informality through the absence of one or more of these connections - but is also driven by both histories of state marginalisation and limited organisational capacity within the informal economy. ${ }^{7}$ In the context of the current crisis, with informal workers often disconnected from state institutions, their vulnerability to both the health and economic effects of the pandemic is exacerbated in at least three central ways. First, informal workers are less likely to have access to health care and other workplace-related protections, reflecting longstanding societal divisions in access to essential public goods. Second, informal workers are more likely to be dependent on informal social welfare and face new debt as informal social safety nets collapse. Third, informal workers have lacked access to many state-funded crisis relief programs. These dynamics both exacerbate and reinforce longstanding inequities between those connected to and disconnected from the state. ${ }^{8}$

\subsection{Lack of access to health care}

In the context of a pandemic, 'the ability to access quality health care can become a matter of life and death' (ILO 2020a: 3). It is estimated that half of the global population lacks access to essential health services and about 40 per cent of people are not affiliated with a publicly mandated programme that guarantees access to health care, though with massive differences between regions and income groups (WHO and World Bank 2017; ILO 2017). Informal workers' ability

6 This does not mean that informal workers are disconnected from all state institutions, while patterns of disconnection differ across different regions and among sub-populations of informal workers. This recognises, for instance, the diversity of state actors involved with registration programmes (Gallien and van den Boogaard 2021, forthcoming), as well as the reality that more marginalised populations in the informal economy, including women and migrants, are less likely to have interconnections with the state.

7 As has been well established, in many contexts informal workers are not well-organised or mobilised, while their organisational structures may be particularly vulnerable to co-optation (Lindell 2010; Meagher 2014; Kabeer, Milward and Sudarshan 2013), with policymakers correspondingly giving less priority to their needs and interests. Some sub-sections of informal workers may face particularly challenging constraints to organising, including those working in sectors that are less visible, such as domestic work. While there is increasing scholarship on the political standing and influence of informal workers in various contexts (e.g., Holland 2015, 2016; Tendler 2002), policy outcomes during the pandemic have shown the ways in which representation shapes outcomes and access to relief, as we will show below.

8 Effectively, the politics of disconnection during a pandemic serve to 'socially pattern disease and... reinforce or exacerbate hierarchical distinctions between different members of the body politic' (Chigudu 2019, 417; see also Dionne and Turkmen 2020). 
to access health care is substantially lower than for those in formal employment (e.g., Alfers 2013; WIEGO 2020a), while evidence suggests that the barriers to accessing health care and aversion to hospital care are particularly significant among informal workers (e.g., Sychareun et al. 2016). Even where health care can be accessed, it frequently comes with additional expenses that exacerbate the economic hardships of informal workers. ${ }^{9}$ Prior to the pandemic, for instance, it was estimated that 800 million people globally spend at least 10 per cent of their household budget on health care each year (WHO and World Bank 2017).

Informal work also frequently overlaps with other forms of social, economic, or political marginality that can complicate access to health infrastructure. Perhaps most critically, informal migrant workers face multiple overlapping vulnerabilities that affect their access to appropriate care. These include a lack of entitlement to health care, linguistic barriers that hinder communication with service providers, a lack of access to facilities in underserved locations, limited awareness of their right to receive health care where it exists, and an unwillingness to come forward for care due to fear of arrest and/or stigmatisation (Guadagno 2020). At the same time, the pandemic worsened health and sanitation conditions for many informal workers. For example, in Uganda, lockdown directives and the suspension of public transport forced informal market vendors to live in markets, with poor sanitation and hygiene facilities (Odinga 2021).

\subsection{Exclusion from social protection and reliance on informal social welfare}

Informal workers are frequently excluded from social welfare and protection programmes that could alleviate some of the negative impacts of the crisis, as they usually cannot rely on protection through social insurance or povertytargeted social assistance schemes (Alfers 2020; ILO 2018; ILO 2020d; Medina and Schnieder 2018; WIEGO 2019). ${ }^{10}$ instead relying largely on informal institutions of social welfare through family networks or community organisations. As these networks have been increasingly exhausted as a source of capital as a result of the pandemic, informal workers have been forced to search for new forms of borrowing. Given pre-existing low levels of capital stocks and savings, early evidence suggests that debt burdens have increased substantially in some contexts, exacerbating pre-existing economic vulnerability (e.g. Guérin et al. 2020; SEWA 2020a). ${ }^{11}$ For example, in Thailand, Malaysia, Indonesia and

9 While rigorous studies of the effect of user fees for overall access to health are lacking (e.g., Lagarde and Palmer 2011), there is significant evidence that user fees are regressive, impacting the poorest to a greater extent, with a particularly negative impact on women (e.g., Ekwempu et al. 1990; Nanda 2002).

10 Of course, many social protection programmes do not necessarily exclude informal workers, particularly where they are targeted based on indicators of poverty. However, even as a sub-group, informal workers are more likely to be excluded from schemes

11 Moreover, as unsecured debt has been harder to access, there has been an emergence of new forms of secured debt that threaten household assets (see e.g., Guérin et al. 2020). 
Myanmar, 'the patchiness and inadequacy of government social aid during the pandemic - especially for workers in the informal economy - has exacerbated household indebtedness as many have had to take new loans simply to pay for survival' (McCarthy et al. 2021). As women already had less access to capital than men (e.g., Delecourt and Ng 2019), gendered inequities are further exacerbated. Compounding the problem, many informal workers lack access to formal sources of finance, leaving them to rely on private moneylenders or commercial partners such as employers, customers, or wholesalers (Martinez and Rivera-Acevedo 2018; Guérin 2014; Guérin et al. 2021). ${ }^{12}$ While the former may charge extortionate fees, increasing debt to the latter risks enabling forms of indentured labour. Regardless of the source, increasing debt is likely to have long-term implications for informal livelihoods, poverty, and the nature of urban spaces. ${ }^{13}$

\subsection{Inaccessible crisis relief}

Disconnection from state institutions has persisted in the context of state-led crisis responses. Arguably, the most significant effect of the crisis on low-income communities in the global South has been the result of informal workers' exclusion from rapid-response relief and social protection programmes, with relief programmes demonstrating an overwhelming bias to the formal sector across diverse contexts (e.g., Rateng 2020a; Battersby 2020; Afshar and Devenish 2020; Qiang and Kuo 2020). Thus far, state-led crisis relief has primarily been based on two pre-existing intersections between states, businesses, and citizens, with relief channelled through formal sector businesses or targeted to vulnerable communities that were previously registered in some form by the state. While it is understandable that states used these pre-existing intersections because of the need for timely payments, they critically have often excluded informal workers.

First, a substantial set of emergency relief globally has been distributed either to or through formal sector businesses (e.g., Gentilini et al. 2020; Raga 2020), which are often well-connected to the state through multiple channels. Forms of relief distributed in this manner include furlough and wage support programmes for formal sector businesses, including small businesses and self-employed individuals in the formal sector, and temporary policies that have helped businesses cope, including tax reliefs, tax filing extensions, (e.g. Mascagni et al.

12 We do not presume that there is a clear binary between formal and informal finance or financial inclusion and exclusion.

13 For instance, informal workers with previously limited margins of survival will find it difficult to undertake business ventures, with informal workers increasingly shifting into subsistence agriculture or other modes of survival. 
2020). ${ }^{14}$ Identification of recipients for these types of relief has typically been facilitated by pre-existing tax registrations of formal businesses and selfemployed entrepreneurs (see e.g. ILO 2020b). Naturally, these types of relief have been unavailable for informal workers, including those employed 'off the books' in the formal sector.

A second set of emergency relief programmes has been delivered through preexisting programmes and registers that target socio-economically vulnerable communities or has required prior registration with other government agencies. Indeed, the United Nations (UN) (2020: 9) suggests that best practice responses to the crisis use pre-existing national social protection programmes. Notably, some relief programmes have recognised informal workers as a particularly vulnerable group, while the UN (2020: 9) suggests that basic social protection be extended to informal workers - though with providing clear guidance about how to target these workers. Accordingly, most programmes have targeted relief using pre-existing registers of vulnerable populations without a specific focus on informal workers (e.g., Rateng 2020b; Kimani et al. 2021). ${ }^{15}$ While some informal workers overlap with groups included in these registers, vulnerability is an imperfect proxy for informality, leading these programmes to exclude significant subsets of informal workers.

Meanwhile, requiring prior registration with social protection programmes or other government agencies has been a common feature of many relief programmes (ILO 2020d: 6) and have limited informal workers' ability to access relief. For example, in South Africa, access to relief for informal shops, known as spazas, included exclusionary conditions including registration with the South African Revenue Service and South African citizenship (DSBD 2020). ${ }^{16}$ Accordingly, in many such contexts, government responses and conditions for relief 'have demonstrated considerable bias towards the large-scale formal actors and pushed towards formalization of the informal sector through the conditions' (Battersby 2020; see also Rateng 2020a). ${ }^{17}$

14 While wage subsidies represent a smaller percentage of crisis-related relief programmes in LMICs (19 per cent) and LICs (9 per cent) relative to the world at large (31 per cent), they still represent a considerable proportion of relief strategies (Ritchie et al. 2020).

15 These include, for instance, programmes that have targeted workers on registers that indicate eligibility for subsidised foodstuffs, fuel, or health care, as has been the case in Morocco (OECD 2020), or communities with high poverty rates, as has been the case in Pakistan (Bourgault and O'Donnell 2020b).

16 Indeed, many spaza shops 'lack the means to apply' for relief, reflecting the reality that 'the government did not engage with informal traders to co-design their strategy' (du Toit and Mitlin 2020). Other barriers to receiving relief emerged in this context given the practical challenges of having identity authenticated, with beneficiaries having to sleep in queues overnight at government offices to receive grants when eligible.

17 As an example of voices calling for formalisation throughout the pandemic, Qiang and Ghossein (2020) argue that 'The current pandemic has made it more urgent to seize the opportunity for unlocking the potential of the informal sector' through formalisation. 
Certain subpopulations of informal workers are particularly likely to remain invisible to state-led relief programmes. Informal migrant workers, for instance, are often both absent from these forms of state databases and unable to return to their home countries as a consequence of lockdowns. The dynamics of exclusion during the crisis thus reflect a long-standing history of informal work overlapping with multiple dimensions of disconnection from the state. ${ }^{18}$ They also highlight, again, the importance of recognising heterogeneity and contextspecificity within the informal economy, and of recognising that even programmes aimed specifically at informal workers may risk focusing on 'easy to reach' informal workers, missing out communities at the intersection of multiple marginalities. 


\section{The new politics of connection: Crisis and institutional change}

While the politics of disconnection have exacerbated inequality and reinforced exclusion of informal workers, the Covid-19 pandemic has in some cases served to draw attention to the unique vulnerabilities associated with informal work. In many contexts, new points of connection between informal workers and states have been forged, including novel efforts to deliver short-term relief to informal workers or register informal workers for social protection programmes, to control and regulate informal work, and to expand bargaining between informal workers' organisations and the state. Critically, new points of connection between informal workers and states are not necessarily one-directional or of a single use; instead, they can be used to both support informal workers in novel ways while also introducing new measures of control and extraction.

The pandemic is thus functioning as a catalyst for change, while also shaping the structure of new interconnections and affecting the renegotiation of pre-existing ones. For one, the fiscal context of the crisis has shaped the nature of the relationship between the state and informal workers. In the early days of the crisis, there was a willingness to expand public spending in order to support vulnerable groups. ${ }^{19}$ Especially in developing countries, however, crisis-related spending has also presented significant concerns about growing debt, inducing policymakers to seek new revenues, including from the informal economy. Further, the crisis has shaped the discourses around 'informal' and 'essential' work and the boundaries and rights of citizenship, in turn shaping the relationship between the state and informal workers. On the one hand, renewed public attention has reinforced a longstanding framing of informal work as a danger to public health and safety and, hence, as something that needs to be controlled and contained (e.g., Collyns et al. 2020). On the other hand, there has been increased recognition of the essential nature of informal work to the functioning of economies and societies (e.g., WIEGO 2020b; Sabatini 2020). The ways that states respond to these shifting fiscal pressures and narratives have significant implications for the nature of new interconnections between states and informal workers. These interconnections are likely to continue to be formed and restructured in the post-crisis context, with lasting and significant effects for the relationship between the state and the informal economy.

19 The Organisation for Economic Co-operation and Development's (OECD) Policy Responses to Coronavirus document for example specifically recommends that countries strengthen national and subnational-level support to vulnerable groups to limit further deterioration in their circumstances and to strengthen inclusiveness' and discusses a range of interventions that have been visible across 2020 (OECD 2020). 


\subsection{Crisis Relief: New intersections, old exclusions}

While few relief programmes during the early months of the pandemic targeted informal workers, some countries have since tried to specifically target them through short-term cash transfer programmes and temporary extensions of social protection programmes to previously excluded groups (UN 2020; ILO 2020d; Schwettmann 2020). ${ }^{20}$ Prominent examples include income replacement measures for informal workers in Thailand and Peru (UN 2020: 9) and targeted cash transfers to informal fruit and vegetable sellers in Burkina Faso and informal workers Morocco and Togo (Kaboré 2020; OECD 2020a; ILO 2020d: 5). In many cases, and in line with previous evaluations of such efforts, these new programmes face significant challenges in identifying and delivering benefits and risk reproducing old exclusions (see e.g., Kimani et al. 2021). For example, a survey of informal workers in $\mathbf{2 0 2 0}$ found that less than half of informal workers received cash or food benefits in 12 cities where governments announced relief measures to support vulnerable groups, while the level of relief provided was insufficient to have a positive impact on food security and coping strategies (Alfers et al. 2020).

Even new programmes specifically targeted at informal workers have often required previous registration with government agencies, as described above. Relief strategies have thus struggled to reach those that were excluded by previous programmes. Moreover, by relying on brokers and intermediaries known by the state, they reinforce power and exclusionary dynamics through the flow of information, capital, and control. For example, in Kenya, the government relied on chiefs to provide community members' names and phone numbers to the national government to support a database that could administer relief, though the inclusiveness of these lists was undermined as chiefs were 'deemed to have favored certain locals, as well as undeserving relatives and friends residing outside their locations' (Rateng 2020a). In this context, '[g]etting a cash grant depends on who you know' (Rateng 2020b).

Many of the systematic challenges of crisis relief programmes reflect longstanding exclusionary dynamics with regard to informal workers (e.g., Meagher and Lindell 2013). First, the lack of clear communication channels between many informal workers and state agencies can mean that information about relief programmes does not reach eligible informal workers. For example, workers in some sectors, including domestic work and industries where subcontracting of informal work is common, are less likely to have an intermediary connection with the state, such as a labour organisation that may share

20 The pandemic has likewise drawn attention to the need to reinforce and extend national social protection systems on a more permanent basis (ILO 2020d; Alfers 2020; Lind et al. 2021), though the outcomes of this renewed attention are not yet certain. 
information with them. In these contexts, employers may either not have appropriate information about benefits for employees or not share that information, increasing the relative invisibility of workers to the state.

Second, people engaging in informal work do not always define themselves as informal workers - for example, describing their work as something they just to do survive rather than a 'real' business - and thus may not be aware of their eligibility for various programmes. Evidence suggests that this is particularly likely among female informal workers (Haque et al. 2020). For example, in India, female agricultural workers who work on family land frequently describe themselves as housewives, even though the majority of non-harvesting activities are done by them, alongside all livestock care and business activities (Rai 2019; Kulkarni et al. 2020). Similarly, home-based garment workers often do not acknowledge their contribution to the supply chain, compounded by the official lack of recognition of home-based work as a trade (Mahmud and Huq 2013).

Third, low levels of education among informal workers may mean that they face additional challenges in applying for relief programmes, while the time burden of applications can be prohibitive (e.g., Harlin 2020; Alfers 2013). Technological requirements, such as registration through digital platforms or access to formal banking to receive relief immediately exclude those that do not have access to use these technologies or services (ILO 2020d; Adegoke 2020; Afshar and Devenish 2020). Where registration requirements present burdens to accessing relief, women and other marginalised groups are most likely to be excluded. In Pakistan, for example, the reliance of the Ehsass Emergency Cash Program which purposively targets women - on mobile phone registration and national identification has led to women making up only 43 per cent of recipients overall, with up to 78 per cent of women in poverty excluded as direct recipients (Bourgault and O'Donnell 2020b). Worsening pre-existing gender biases in targeting and identification, during the crisis women have been more likely to give up phones and internet access before men within households. ${ }^{21}$

Fourth, there are good reasons to believe that limited trust in state institutions, histories of harassment at the hands of state agents, and the precarious legal position of many informal workers may have left them suspicious of new state efforts to register them (e.g., Narula 2020). This is particularly relevant given widespread evidence that trust in the state and the public health system improves utilisation rates of health systems and underpins the resiliency of health systems (e.g., Blair et al. 2017; Vinck et al. 2019). During the Ebola epidemic from 2014-16, for example, longstanding relationships of neglect by the state, regional and demographic inequality, and experiences of structural

21 For example, Alvi et al. (2020) report that as households in Gujarat state in India faced income losses, women's cell phones were one of the first expenses to be cut from households' budgets. 
violence fuelled distrust of the Sierra Leonean state and ultimately impacted some individuals' willingness to engage with the public health system (see e.g., Wilkinson and Leach 2015; Wigmore 2015; Christensen et al. 2020). The importance of trust in the context of the current pandemic is further reinforced given widespread evidence of false information being shared about Covid-19 (e.g., SEWA 2020b; Hassan 2020), reminiscent of the role of rumours, lies, and disinformation in fuelling distrust in the state and public health system during previous epidemics (see e.g., Wigmore 2015; Chigudu 2020).

Consequentially, access to new forms of targeted relief has varied across subpopulations, with early evidence making clear that new interconnections with the state have been particularly unlikely to be established with women (e.g., Pande et al. 2020), reflecting longstanding gendered challenges of targeting, access, and uptake of social protection programmes (e.g., Lund and Srinivas 2005; Bourgault and O'Donnell 2020a). Nevertheless, this gendered outcome has not been universal - in some cases, including Dakar, Delhi, Mexico City, and Durban, women have been more likely than men to receive relief, reflecting the reality that relief is more likely to reach those previously covered by some form of social assistance (such as families with children) than those previously uncovered (Alfers et al. 2020: 3). Once again, recognising heterogeneity within the informal sector itself provides a critical angle to understanding and evaluating the effects of these programs.

\subsection{Connection, taxation, and control}

While states have built new intersections with informal workers to facilitate the channelling of aid and relief, such points of connection may be limited to the short term given their substantial costs and the growing fiscal pressures facing states. Rather than solely providing relief, new points of connection have also emerged in line with two central state logics: the control of public space and taxation. Critically, regardless of their initial intent, many new points of connection between states and informal workers can provide states with the necessary tools - information about informal workers, points of contact, and channels of communication - that can subsequently be employed to restrict informal work, restructure informal spaces, or extract revenue from informal workers.

First, state reactions to the Covid-19 pandemic have typically included substantial restrictions on the use of public and private space, representing 'an exceptional exertion of state authority' (Nyama et al. 2020). While measures have been generally broad and aimed at formal and informal enterprises alike, informal workers have been particularly affected for several reasons, including their frequent inability to work from home, take advantage of furlough schemes, or swiftly adapt workspaces to comply with state-sanctioned health criteria (Noko 
2020; Adegbeye 2020; du Toit and Mitlin 2020). In some contexts, poor populations and informal workers have been particularly targeted in the enforcement of lockdown regulations - with, for example, almost a quarter of a million people arrested for contravening regulations in the first two months of the lockdown in South Africa (BusinessTech 2020). Similarly, in Nairobi there has been an increase in human rights violations, police violence, and harassment of small and micro business operators as a result of the pandemic (Kimani et al. 2021).

Aside from more broadly applied lockdowns, some states have given increased policy attention to restructuring informal economic spaces, often underpinned, as discussed above, by public discourse and misinformation that associates informal work with a lack of hygiene and the spread of the pandemic (e.g., Collyns et al. 2020). In some cases, these discursive dynamics have increased the vulnerability of informal workers by inciting prejudice, social sanctions, harassment, and violence. For instance, during the pandemic, a municipal government in Mexico City confiscated street-vendors' tricycles with the justification of preventing a 'sanitary risk' (Harvey with Focal Cities team 2020), while local authorities in Zimbabwe destroyed informal vendors' stalls during a lockdown in order to ensure that cities are 'clean, orderly and well-managed' (Minister of State for Harare Oliver Chidawu cited in Mukeredzi 2020). These dynamics reflect longstanding patterns of state engagement with informal workers and public space, with informality often being stigmatised and informal workers often blamed for problems over which they have little control. ${ }^{22}$

Second, while states are thus reinforcing old patterns of control of informal workspaces, increasing fiscal pressures have led to greater policy attention to taxing the informal economy - long on the policy agenda in the global South (Moore 2020; Gallien et al. 2020; Gallien and van den Boogaard 2021, forthcoming). While the early phase of the pandemic saw widespread expansionary fiscal policy, governments around the world - and particularly in low-income countries - quickly began discussing the pressing need for revenue (e.g., ATAF 2020), with renewed policy attention focused on the revenue potential of the informal economy (ATAF 2021; Monye and Abang 2020; Naija247news Editorial Team 2021; Emejo 2020). In Algeria, for example, President Abdelmadjid Tebboune has pointed to new revenue raised from the informal sector as an alternative to international borrowing in order to finance the crisis (Hamadi 2020). Critically, taxing the informal economy may be facilitated by newly created registers of informal workers for crisis relief programmes, with new information provided to the state potentially facilitating the identification and

22 For instance, some states have a longstanding history of demolishing informal workplaces and settlements (e.g., Resnick 2019; Wilkinson 2020), a phenomenon Chigudu describes as revealing the state's 'arbitrary and spectacular power thinly veiled under appeals to creating urban order' (2019: 433). 
taxation of informal workers (Gallien and van den Boogaard 2020). ${ }^{23}$ The involvement of tax registers in the organisation of crisis relief programmes has been notable in multiple countries, such as Jamaica, where access to the Covid19 Allocation of Resources for Employees programme was dependent on the provision of a tax registration number, despite being open to informally employed workers (Jamaica Observer 2020). The risk of crisis relief programmes being used to extract new revenues from the informal economy has been a serious concern of informal workers and advocacy groups in a range of countries (e.g., VISET 2020). While efforts to extract more taxes from informal economic clusters are frequently framed as creating a 'level playing field' or generating positive externalities for informal workers themselves, the empirical experience with such initiatives has often not merely been disappointing on revenue grounds, but highly counterproductive from developmental, fairness and equity perspectives. ${ }^{24}$

Both state controls on informal workspaces and taxation of informal workers provide reminders that new points of connection between informal workers and states are not necessarily one-directional or of a single use. They can be mobilised both to support informal economic clusters and to control and extract revenue from them. This provides relevant context to the reluctance of some informal workers to engage with state structures, even during the crisis. For example, groups of informal workers, such as undocumented migrants or those working or living in refugee and detention settlements, have expressed reluctance in engaging with state structures (see e.g., Lim 2020).

\subsection{Non-state intermediaries, co-production, and labour organisation}

Naturally, new interconnections between informal workers and the state are not created in an institutional vacuum, but are shaped by non-state intermediaries, such as informal associations, labour unions, or non-state service providers. In the context of the crisis, these intermediary actors may establish or reinforce supplementary relationships with the state; operate parallel to, instead of with or against, the state; or create new points of tension and competition with the state. We consider these possibilities in the context of non-state service provision and informal labour organisation, paying particular attention to the ways that these intermediaries shape the relationship between the state and informal workers, as well as state capacity and authority.

First, in contexts where states provide insufficient relief to informal workers, nonstate actors play a large role in supporting social welfare and providing public

23 It has been long understood that legibility is an important requirement of taxation, state capacity, and state control (e.g., Lee and Zhang 2016).

24 For a more thorough discussion of these issues, see Gallien et al. (2021), Gallien and Van den Boogaard (2021, forthcoming), Moore (2020), Joshi et al. (2014). 
goods either in parallel to or in conjunction with the state. ${ }^{25}$ During the crisis, non-state actors have frequently taken on more responsibility to provide essential services to informal workers, operating 'below', 'beside', and 'beyond' the state (Bellagama and Klute 2008). For example, through their childcare centres, India's Self-Employed Women's Association (SEWA) has been providing food to young children and their families during the crisis, while its lowcost health centres have been providing medicines and creating affordable hand sanitizers (WIEGO 2020c; Sen and Haque 2021). Similar examples in other contexts are abundant (e.g., Scheepers et al. 2020; Rateng 2020b; Conteh et al. 2021). Dynamics of coproduction and supplemented service provision are also evident in the role that non-state community actors have played in building trust in and extending access to public health care systems and information, particularly among informal workers (e.g., WIEGO 2020c). ${ }^{26}$

While in some contexts, working with non-state intermediaries has improved the design of relief strategies by ensuring that they are embedded in local contexts, the use of intermediaries in identifying beneficiaries or delivering relief can lack transparency and reinforce inequalities, as described above. In other cases, state reliance on non-state actors has represented an offloading of government responsibility and a 'moralising bias' against what some see as 'government handouts' (du Toit and Mitlin 2020). For instance, the Solidarity Fund in South Africa, created to enable the private sector and civil society to support the Covid19 response, stopped providing emergency food rations, with the interim CEO noting, 'We cannot perpetuate a society where we are always benefactors of handouts. We need to activate communities to do things for themselves' (cited in Hosken 2000). Second, in some contexts, informal associations and labour unions are increasingly building or reinforcing points of connection with the state in order to better represent the interests of informal workers (Schwettmann 2020; Afshar and Devenish 2020). Informal workers' organisations and international networks have issued various statements and demands to policymakers to address issues that are of increased importance as a result of Covid-19, including income security; food distribution; tax, fee, and rent relief; job security; health care; and occupational health and safety (WIEGO 2020c). In some instances, this has resulted in positive government responses, including recognition of the need to address the welfare of informal workers. For example,

25 This reflects what Post et al. (2017: 955) describe as the 'supplemented state' model of hybrid service delivery. In effect, non-state actors may work to achieve goals for which 'formal institutions were designed, but failed, to achieve' (Helmke and Levitsky 2004: 729) in line with co-production, with citizens 'augment[ing] or contribut[ing] to the actions of public agencies and invok[ing] conjoint behaviour' (Joshi and Moore 2004: 47).

26 This in line with robust evidence of the ways that non-state actors can encourage case reporting in the context of a public health crisis and increase access to treatment (e.g., Tsai et al. 2020; Christensen et al. 2020; Kruk et al. 2015). Non-state actors have furthermore been called upon to co-develop more locally appropriate containment measures in recognition of the ineffectiveness of blunt instruments, such as blanket lockdowns, when it comes to the informal sector (Wilkinson 2020; Patel 2020). 
the South African Informal Traders Alliance, WIEGO, and the Joburg Informal Traders Platform called for informal workers to be exempted from lockdown measures (Muller 2020), leading to the government revising lockdown measures to exclude some informal food vendors (Battersby 2020).

Despite some productive engagement, however, the challenges associated with organisation in the informal economy means that there is both a dearth of informal associations capable of mobilising advocacy efforts and an uneven distribution of representation within the informal economy (Lindell 2010). At the same time, even where informal labour organisation is possible, there is no guarantee that the state will engage with these groups in good faith. As noted above, new points of connection between informal workers and the state do not inherently lead to productive relationships and positive outcomes for informal workers. Here it is critical to consider the role of informal workers alongside other groups vying to influence state policy in the post-pandemic context. Formal actors, who are potential targets for post-pandemic revenue-raising, may have an explicit interest in arguing for greater taxation of informal sector actors, while often enjoying greater political representation and advocacy through lobby groups. This highlights the importance of considering both changes in the vertical relationship between informal workers and the state and in the horizontal relationships between informal workers and other societal actors - both as a risk and as an opportunity for solidarity. ${ }^{27}$ 


\section{Informality and the politics of the pandemic}

The dynamics of connection and disconnection discussed above not only have significant and lasting effects on the lives and livelihoods of informal workers but also provide critical insights into the politics of the pandemic. They can bring greater nuance to our understanding of the role and limitations of the state in responding to crisis. Analyses of the crisis in the social sciences have brought renewed attention to the study of the state, in line with the longstanding trend of 'bringing the state back in' (e.g., Skocpol 1985; Centeno, Kohli, and Yashar 2017). Many have highlighted that only the state has the power to introduce the broad containment and enforcement measures that the crisis requires, while state capacity, trust in the state, and structural inequities resulting from state policy centrally shape the effectiveness of those measures (e.g., Bosancianu et al. 2020; Gisselquist, Vaccaro and UNI-WIDER 2021; Amoah 2020).

Among studies of the state in the context of the pandemic, there has been a particular analytical focus on state capacity, following significant variation in state responses and ability to institute effective lockdowns, organise contact tracing systems, and communicate credible public health strategies. ${ }^{28}$ Much of this work has focused on the ability of states to effectively control the public health crisis and to offer social relief. Analyses of the state's capacity to engage with informal workers have notably been largely absent. ${ }^{29}$ This is problematic: analyses of the state and state capacity in relation to the crisis are critically incomplete without accounting for variation in the ways that states engage with the informal economy and their heterogeneous capacity do so effectively.

Empirically, studying informal work can help us to better understand the effectiveness and reach of state institutions. The politics of connection and disconnection in relation to informal workers presents a mechanism through

28 Along with regime types, state capacity stands as the most referenced evaluative framework within the emerging literature on the comparative politics of the pandemic. By August 2020, a search for 'Covid-19' and 'state capacity' in Google Scholar already found over 700 papers. A focus on state capacity has been particularly prevalent in analyses of jurisdictions that handled the early stages of the pandemic relatively well, such as Hong Kong (Hartley and Jarvis 2020) and Singapore (Woo 2020), as well as of comparatively bad performances, including by the United Kingdom and United States. As Ang (2020) notes 'democracy by itself is no guarantee of efficacy; it must also be combined with wise leadership and state capacity'.

29 This in part can be explained by the fact that informal dynamics have not been systematically captured by the most popular empirical bases for comparative work on Covid-19 and state capacity - policy trackers and publicly available quantitative metrics, such as number of infections, deaths, or changes in employment and GDP. Our comments here relate primarily to discussions in political science and development studies. While there has been some attention to informal workers during this crisis, some of which we cite in this paper, this has primarily come from NGOs and work on inclusive economies. 
which we can assess how effectively states have managed the crisis. For instance, common metrics of state capacity consider how effectively states have implemented emergency social protection and formal tax relief, rates of unemployment, or how quickly formal businesses are able to re-open after lockdowns, though often fail to consider individuals and businesses that are invisible to or ignored by state programmes (e.g., Lim 2020; OECD 2021). Given that over half of the global labour force is informally employed (ILO 2019), understanding the nature of state engagement with informal workers is necessary to more accurately assess state capacity to manage the economic effects of the crisis. A focus on informality will also provide insight into the importance of trust and political legitimacy to states' ability to 'get things done' (Centeno et al. 2017: 13; see e.g., Hartley and Jarvis 2020). As highlighted above, trust is particularly relevant in the context of politically and economically marginalised groups, which often work informally. Examining informal workers' trust in the state helps to contextualise and politicise the idea of trust as a product of longstanding structural marginalisation and the broader histories of the relationships between the state and particular groups within its territory.

A closer consideration of the relationship between states and informal workers can also deepen theoretical discussions of state capacity. First, the ability of states to draw on pre-existing relationships with informal economic clusters or construct new points of connection in order to deliver rapid relief makes clear that state capacity is shaped by the ability to institutionalise or mobilise interactions with societal actors. Whether organised labour, business communities, diaspora populations, or workers in the informal economy, state capacity is mediated through broader political relationships and engagement with social forces. ${ }^{30}$

Second, the ways that the state interacts with informal workers may shape citizen expectations of the state, creating positive or negative reinforcing impacts on state capacity. For instance, where the state newly engages with informal workers and institutionalises relationships with them, whether independently or through intermediaries, it may positively reinforce its capacity to interact with and serve citizens more inclusively. Indeed, there is increasing discussion of what states owe informal workers, including migrant workers, with increasing popular attention paid to their work conditions, food security and healthcare (WIEGO 2020c). At the same time, in some contexts the crisis is shifting expectations of the state and citizenship, with calls not just for emergency relief, but improved access to basic services - especially with respect to sanitation, water provision, and hygiene - 'beyond an emergency response' (e.g., Nyama et al. 2020; Balbuena and Skinner 2020). In this way, the crisis is enabling and reinforcing

30 This represents the state's political settlements, to use one common theoretical formulation (Khan 2011), or a classic state-in-society model, to use another (Migdal 2001; Migdal, Kohli and Shue 1994). 
what Chigudu $(2019,432)$ describes as an expansion of the 'politics of expectation'.

While growing citizen expectations of the state may lead to greater political mobilisation and an expansion of the responsibility of the state, however, it is also possible that if the state does not fulfil expanding citizen expectations, the shifting 'politics of expectation' may lead to increased distrust in the state, a reinforced reliance on non-state actors or self-help, and exit from the state and state services (see Chigudu 2020). Whether or not the state responds to expanded demands of citizenship, access to essential public goods shapes citizens' 'lived citizenship practices, community mobilizations, and intersectional claims-making to... citizenship, recognition, and belonging' (Sultana 2020). ${ }^{31}$ The impact on state capacity, whether positive or negative, may be self-reinforcing, in part because of the path dependent nature of many of these institutional relationships and in part because of the challenges of reining in fundamental expectations about the rights of citizenship once they have been accepted (e.g., Pierson 1994).

Third, and building on the previous points, considering informal workers in the context of the pandemic serves as a critical reminder that state capacity is embedded in political and institutional histories. While the relative lack of connections between states and informal workers is frequently attributed to weak state capacity to 'penetrate', control or 'formalise' informal economies, this perspective has been significantly challenged in recent years. Both state disconnection from informal economies and the nature in which connections are organised are embedded in political choices and a wider set of power relations (Holland 2016; Tendler 2002; Gallien 2020). Paying attention to informality in the context of the crisis helps us to see that state responses have heterogeneous effects on different groups, shaped by political and institutional histories of inclusion and exclusion. Stronger state capacity does not guarantee more positive outcomes for informal workers; rather, outcomes depend on what the state does with its capacity in relation to different groups and how these groups are able to negotiate new forms of state engagement, navigate changing institutional environments, or organise to resist forms of state control. For example, greater state capacity may imply more severe restrictions on the movement of informal migrant workers or street-vendors or the destruction of their places of work, while simultaneously enabling relief for certain groups of informal workers, including those that are better educated or politically connected. Analysing the state in the context of informality can thus provide both greater nuance in our empirical understanding of the heterogeneous effects of the crisis and a conceptual framework to understanding the link between these outcomes and state capacity.

31 This is in line with a growing body of literature that views citizenship as contingent on interactions between the state and citizens (e.g., Roitman 2007; Anand 2017; Hern 2019). 


\section{Conclusions: The state, informal workers, and the long shadow of the pandemic}

The Covid-19 pandemic has changed the ways that states engage with informal workers. Drawing attention to the heterogeneous dynamics across states and among different groups within the informal economy, we have drawn attention to the significance of the politics of connection and disconnection during a global pandemic. As we have highlighted, the effects of the crisis for both states and informal workers have been shaped by the absence, existence, and nature of the interconnections between states and informal economies. This is not altogether surprising: in recent years, almost all prominent proposals on how to improve informal livelihoods - from top-town formalisation and registration efforts to informal organising and collective action strategies to support for 'inclusive economies' - have sought to restructure the relationship between informal workers and states. Meanwhile, theoretical approaches to informality have highlighted that the interaction between formal and informal institutions is critical to understand institutional outcomes, that the lines between them are not always clearly drawn, and that states' involvement in informal institutions needs to be considered (Helmke and Levitsky 2004; Meagher 2007; Gallien 2020). While the recognition of the importance of informality to statehood, and vice versa, is thus not novel, we highlight its substantive relevance to the current politics of the pandemic.

The pandemic has been a catalyst for rapid institutional change at the intersection between states and informal workers. It is enabling reforms registration efforts, strategies to expand taxation, economic support programmes - that have long been used by state actors but often previously lacked resources or incentives for implementation. The context of the pandemic - an increasing acceptance of state control of public space, rapid fiscal expansion followed by increasing concerns about public debt and changing and often contradictory discourses around informality - shapes the intersections between informal workers and the state, as well as the relative abilities of different actors to react to and cope with reforms. This is critical in light of the heterogeneity of actors and marginalities within the informal economy. In particular, the crisis has exacerbated challenges facing vulnerable groups within informal economies, including migrants, women, and those engaged in atomised activities without labour representation. Critically, new interconnections between the state and informal workers will have effects that will outlast the immediate crisis. Evidence is still emerging on the nature and impact of these dynamics and should continue to be tracked and explored over the coming years. Nevertheless, the very fact 
that informality is being overlooked by both scholars analysing the crisis and policymakers responding to it implies an urgent need to highlight its importance in shaping institutional change and the effectiveness of crisis responses.

As we note above, new institutional dynamics between the state and the informal economy are of central theoretical significance in at least two ways. First, the rapidly shifting nature of these dynamics provides ample opportunity to test previous theories and accounts of formal-informal interactions. For instance, under what conditions do 'informal institutions sustain or reinforce - as opposed to undermine or distort - formal ones' in the context of the crisis (Helmke and Levitsky 2004: 734)? Where informal workers are better organised, are they more effectively able to demand support from the state? Second, an informality perspective challenges emerging discourses on state capacity in the context of the pandemic. Intersections between states and informal workers - as well as the heterogeneous ability of different groups to mobilise, influence and utilise these intersections - have critically shaped the nature, effectiveness, and outcomes of state responses to Covid-19. An understanding of the significance of these intersections to policy outcomes allows us to better contextualise, qualify and politicise state capacity, highlighting the importance of the relationship between the state and groups within society and their heterogeneous effects on outcomes during and after the immediate crisis.

From this theoretical significance productive avenues for future research emerge. These include more in-depth application of theories of informal institutions to the institutional changes triggered by the crisis, evaluations of the effectiveness of new social protection programmes in targeting informal workers, and deeper exploration of the heterogeneous experiences of different groups within the informal economy. Additional work may track the long-term implications of new social protection and relief programmes for citizen understandings and expectations of citizenship. Research may also usefully draw attention to the ways in which new points of connection are shaped not only by the needs, demands, and organisational capacity of informal workers, but also by the political and historical context in which they are embedded.

Two trends in particular will be of relevance to scholars of informality and the state for years to come. First, as we have noted, the past months have seen broadly divergent narratives around informality, some highlighting its role in 'essential' work, and others reinforcing views about informality as a subversion of state control. These tensions will be exacerbated by changes in the informal sector itself, as sustained high unemployment across the economy will lead to new entrants into the informal economy, displacing and deepening pre-existing vulnerabilities among informal workers. Tracing how these narratives evolve and consolidate will be of particular interest, as will an exploration of their underlying drivers and effects on the expectations of state responsibilities to informal workers. 
Second, sustained fiscal contractions and the related urgency of revenue needs is likely to shape the development and use of new points of connection between the state and informal workers. As we note above, new interconnections are not necessarily fixed in their use, and may transform over time. A key emerging question is then whether fiscal constraints within the recovery period will lead to an increasing re-purposing of these intersections by states. For example, it will be critical to trace the degree to which the increased visibility of some forms of informal work - through, for instance, requirements to register with the state to receive emergency relief - will give rise to new attempts by the state to 'formalise' and especially to tax informal work more extensively. The impacts of such strategies will have heterogeneous effects on different groups, depending on their varying ability to resist additional taxation or to negotiate its terms. While we hope that the Covid-19 pandemic is not here to stay, the ways in which the state interacts with informal workers in its wake will be shaped by the virus' shadow long into the future. 


\section{References}

Adegbeye, O. (2020) 'Why Social Distancing Won’t Work For Us', The Correspondent, 27 March (accessed 19 October 2020)

Adegoke, Y. (2020) 'Digital Platforms Have Been a Boon for Social Assistance in Africa During the Pandemic', Quartz Africa, 9 September (accessed 24 November 2021)

Afshar, C. and Devenish, A. (2020) Reaching the 'Missing Middle': Social Protection for Informal Workers in COVID-19, WIEGO, 1 October (accessed 24 November 2021)

Alfers, L. (2013) The Ghana National Health Insurance Scheme: Barriers to Access for Informal Workers, WIEGO Working Paper 30, Manchester: Women in Informal Employment: Globalising and Organising

Alfers, L.; Ismail, G. and Valdivia, M. (2020) Informal Workers and the Social Protection Response to COVID-19: Who got relief? How? And Did it Make a Difference?, WIEGO Policy Insights No. 2, Manchester: Women in Informal Employment: Globalising and Organising

Alvi, M.; Gupta, S.; Meinzen-Dick, R. and Ringler, C. (2020) Phone Surveys to Understand Gendered Impacts of Covid-19: A Cautionary Note, EnGendering Data blog, 14 June 14 (accessed 19 October 2020)

Amoah, L.G.A. (2020) 'COVID-19 and the State in Africa: The State is Dead, Long Live the State', Administrative Theory and Practice 42.3 355-65

Anand, N. (2017) Hydraulic city: Water and the Infrastructures of Citizenship in Mumbai, Durham and London: Duke University Press

Ang, Y.Y. (2020) 'When COVID-19 Meets Centralized, Personalized Power', Nature Human Behaviour 4: 445-7

ATAF (2021) The Efficient Taxation of the Informal Sector in Africa: ATAF Guidebook, African Tax Administration Forum

ATAF (2020) Outcome Statement, $4^{\text {Th }}$ High-Level Tax Policy Dialogue Between the African Tax Administration Forum and the African Union Commission, 27 August (accessed 19 October 2020)

Battersby, J. (2020) 'South Africa's Lockdown Regulations and the Reinforcement of Anti-Informality Bias', Agriculture and Human Values, 37.3 543-4 DOI: 10.1007/s10460-020-10078-w

Bellagamba, A, and Klute, G. (eds) (2008) Beside the State: Emerging Forms of Power in Contemporary Africa, Köln: Koeppe-Verlag. Köppe

Blair, R.A.; Morse, B.S. and Tsai, L.L. (2017) 'Public Health and Public Trust: Survey Evidence From the Ebola Virus Disease Epidemic in Liberia', Social Science \& Medicine 172: 89-97

Bosancianu, C.M. et al. (2020) 'Political and Social Correlates of Covid-19 Mortality', SocArXiv, preprint, DOI: $10.31235 / o s f . i o / u b 3 z d$

Bourgault, S. and O'Donnell, M. (2020a) Ensuring Women's Access to Cash Transfers in the Wake of COVID-19, Centre for Global Development blog, 30 June, (accessed 20 September 2020)

Bourgault, S. and O'Donnell, M. (2020b) Women's Access to Cash Transfers in Light of COVID-19: The Case of Pakistan, Washington DC, Centre for Global Development

BusinessTech (2020) '230,000 Cases Opened Against People For Breaking South Africa's Lockdown Rules', 22 May (accessed 30 November 2021)

Centeno, M.A.; Kohli, A. and Yashar, D.J. (2017) 'Unpacking States in the Developing World', in M.A. Centeno; A. Kohli and D.J. Yashar (eds), States in the Developing World, Cambridge: Cambridge University Press

Chigudu, S. (2020) The Political Life of an Epidemic: Cholera, Crisis and Citizenship in Zimbabwe, Cambridge: Cambridge University Press

Chigudu, S. (2019) 'The Politics of Cholera, Crisis and Citizenship in Urban Zimbabwe: 'People Were Dying Like Flies', African Affairs 118.472, 413-34

Christensen, D.; Dube, O.; Haushofer, K.; Siddiqi, B. and Voors, M. (2020) 'Community-Based Crisis Response: Evidence from Sierra Leone's Ebola Outbreak', AEA Papers and Proceedings 110, 260-4 
Collyns, D.; Daniels, J.P.; Phillips, D. and Agren, D. (2020) 'Hubs of Infection: How Covid-19 Spread Through Latin America's Markets', The Guardian, May 17 (accessed 14 October 2020)

Conteh, A.; Kamara, M. S.; Saidu, S. and Macarthy, J.M. (2021) 'Covid-19 Response and Protracted Exclusion of Informal Settlement Residents in Freetown, Sierra Leone', IDS Bulletin 52.1, Brighton: Institute of Development Studies, DOI: 10.19088/1968-2021.108 (accessed 24 November 2021)

Delecourt, S. and Ng, O. (2019) Does gender matter for small business performance? Experimental evidence from India, Berkeley CA: Centre for Effective Global Action (CEGA) (accessed 19 October 2020)

Dionne, K.Y. and Turkmen, F.F. (2020) 'The Politics of Pandemic Othering: Putting COVID-19 in Global and Historical Context', International Organization, 74.S1 E213-30 DOI: 10.1017/S0020818320000405 (accessed 24 November 2021)

DSBD (2020) Guidelines for Participation in the Spazashops and General Dealers Support Scheme in Partnership with Nedbank, Department of Small Business Development, Government of South Africa

du Toit, A. and Mitlin, D. (2020) COVID-19: The State Cannot Save Us, African Arguments, 9 June (accessed 24 November 2021)

Ekwempu, C.C.; Maine, D.; Olorukoba, M.B.; Essien, E.S. and Kisseka, M.N. (1990) 'Structural Adjustment and Health in Africa', The Lancet 336.8706 56-7

Emejo, J. (2020) 'Taxation of Informal Sector will Address Budget Deficit, Says FIRS', This Day, 5 February (accessed 24 November 2021)

Gallien, M. (2020) 'Informal Institutions and the Regulation of Smuggling in North Africa', Perspectives on Politics, 18.2, 492-508

Gallien, M. and van den Boogaard, V. (2020) To Fight Covid-19, Only the Formal Economy is Getting Tax Breaks. The Informal Economy May Be Asked to Foot the Bill, The International Centre for Tax and Development blog, 8 April (accessed 20 September 2020)

Gallien, M. and van den Boogaard, V. (2021, forthcoming) 'Rethinking Formalisation: A Conceptual Critique and Research Agenda', ICTD Working Paper, Brighton: Institute of Development Studies

Gentilini, U.; Almenfi and, M. Orton, I. (2020) Social Protection and Jobs Responses to COVID-19: A Real-Time Review of Country Measures, Washington DC, World Bank (accessed 19 October 2020)

Gisselquist, R.M.; Vaccaro, A. and UNU-WIDER (2021) COVID-19 and the state, WIDER Working Paper 2021/80, Helsinki: UNU-WIDER, DOI: 10.35188/UNU-WIDER/2021/018-4

Guadagno, L. (2020) Migrants and the COVID-19 Pandemic: An Initial Analysis, IOM Migration Research Series No. 60., Geneva: International Organisation for Migration

Guérin, I.; Guermond, V.; Natarajan, N.; Joseph, N. and Venkatasubramanian, G. (2021) 'COVID-19 and the Unequalizing Infrastructures of Financial Inclusion in Tamil Nadu', Development and Change 52.4: 927-51 DOI: 10.1111/dech.12674

Guérin, I.; Michiels, S.; Natal, A.; Nordman, C.J. and Venkatasubramanian, G. (2020) Surviving Debt, Survival Debt in Times of Lockdown, Centre Emile Bernheim Working Paper 20-009, Brussels: Université Libre de Bruxelles

Guérin, I. (2014) 'Juggling with Debt, Social Ties, and Values: The Everyday Use of Microcredit in Rural South India', Current Anthropology 55.S9: S40-50

Hamadi, R. (2020) 'Régularisation de l'informel: un chantier colossal et vital', Algeria-Watch, 3 May (accessed 19 September 2020)

Hamdy, S.F. (2008) 'When the State and Your Kidneys Fail: Political Etiologies in an Egyptian Dialysis Ward', American Ethnologist 35.4: 553-69

Haque, A.; Gallien, M. and van den Boogaard, V. (2020) Women Don't Value Their Own Work, India Development Review, 17 December (accessed 24 November 2021)

Harlin, S. (2020) Too Complicated, Too Confusing: Why More Small Businesses Aren't Applying For Coronavirus Relief Loans, and What We Can Do to Reach Them, J-PAL, June 15 (accessed 20 September 2020)

Hartley, K. and Jarvis, D.S.L. (2020) 'Policymaking in a Low-Trust State: Legitimacy, State Capacity, and Responses to COVID-19 in Hong Kong', Policy and Society 39.3: 403-23 
Harvey, J. with Focal Cities team (2020) Do No Harm: Why Harassment of Informal Workers Hurts Public Health and Economic Recovery, WIEGO blog (accessed 20 September 2020)

Hassan, I. (2020) The Other COVID-19 Pandemic: Fake News, African Arguments, 26 March, (accessed 19 October 2020)

Helmke, G. and Levitsky, S. (2004) 'Informal Institutions and Comparative Politics: A Research Agenda', Perspectives on Politics, 2.4: 725-40

Hern, E.A. (2019) Developing States, Shaping Citizenship: Service Delivery and Political Participation in Zambia, Ann Arbor: University of Michigan Press

Holland, A.C. (2016) 'Forbearance', American Political Science Review 110.2: 232-46

Holland, A.C. (2015) 'The Distributive Politics of Enforcement', American Journal of Political Science 59.2: 357-71

ILO (2020a) Social Protection Responses to the COVID-19 Pandemic in Developing Countries:

Strengthening Resilience by Building Universal Protection, ILO Brief, Geneva: International Labour Organization

ILO (2020b) The Impact of the COVID-19 on the Informal Economy in Africa and the Related Policy Responses, ILO Brief, Geneva: International Labour Organization

ILO (2020c) Informal Employment, ILO Thesaurus, Geneva: International Labour Organization (accessed 25 November 2021)

ILO (2020d) Extending Social Protection to Informal Workers in the Covid-19 Crisis: Country Responses and Policy Considerations, ILO Brief: Social Protection Spotlight, Geneva: International Labour Organization (accessed 25 November 2021)

ILO (2020e) COVID-19 Crisis and the Informal Economy: Immediate Responses and Policy Challenge, Geneva: International Labour Organization

ILO (2020f) ILO Monitor: COVID-19 and the World of Work, Third Edition Updated Estimates and Analysis, Geneva: International Labour Organization

ILO (2018) Women and Men in the Informal Economy: A Statistical Picture, Third edition, Geneva: International Labour Organization

ILO (2017) World Social Protection Report 2017-19: Universal Social Protection to Achieve the Sustainable Development Goals, Geneva: International Labour Organization

Jamaica Observer (2020) 'Over 300,000 to Benefit from Govt's CARE Programme', 14 April (accessed 23 September 2020)

Joshi, A. and Moore, M. (2004) 'Institutionalized Co-production: Unorthodox Public Service Delivery in Challenging Environment', Journal of Development Studies 40.4: 31-49

Kabeer, N.; Milward, K. and Sudarshan, R. (2013) 'Organising Women Workers in the Informal Economy', Gender \& Development 21.2: 249-63

Kaboré, R. (2020) 'Message a la nation de son excellence monsieur Roch Marc Christian Kaboré, President du Faso, President du Conseil des Ministres sur la Pandemie du Covid-19', Le Faso, 2 April 2 (accessed 23 September 2020)

Khan, M. (2011) The Political Settlement and its Evolution in Bangladesh, London: School of Oriental and African Studies

Kimani, J. et al. (2021) 'Building Forward Better: Inclusive Livelihood Support in Nairobi’s Informal Settlements', IDS Bulletin 52.1 DOI: 10.19088/1968-2021.104 (accessed 25 November 2021)

Kruk, M.E.; Myers, M.; Varpilah, S.T. and Dahn, B.T. (2015) 'What is a Resilient Health System? Lessons from Ebola', The Lancet 385.9980: 1910-2

Kulkarni, S.; Harshe, P.; Satpute, S. and Bhat, S. (2020) Unlocking the Crisis: Understanding Impacts of Covid-19 and Subsequent Lockdown on Single Women Farmers of Maharashtra, Pune: Mahila Kisan Adhikar Manch (MAKAAM)

Leach, M.; MacGregor, H.; Scoones, I. and Wilkinson, A. (2021) 'Post-Pandemic Transformations: How and Why COVID-19 Requires Us to Rethink Development', World Development 138.105233 DOI: 10.1016/j.worlddev.2020.105233 (accessed 25 November 2021) 
Lee, M. and Zhang, N. (2016) 'Legibility and the Informational Foundations of State Capacity', Journal of Politics 79.1: 118-32

Lim, L.L. (2020) The Socioeconomic Impacts of COVID-19 in Malaysia: Policy Review and Guidance For Protecting the Most Vulnerable and Supporting Enterprises, Geneva: International Labour Organization

Lindell, I. (2010) 'Informality and Collective Organising: Identities, Alliances and Transnational Activism in Africa', Third World Quarterly 31.2: 207-22

Lund, F. and Srinivas, S. (2005) Learning From Experience: A Gendered Approach to Social Protection for Workers in the Informal Economy, Geneva: International Labour Organization

Mahmud, S. and Huq, L. (2013) Home Based Workers in the Export Garment Sector in Bangladesh: An Exploratory Study in Dhaka City, Washington DC: Solidarity Center (accessed 30 November 2021)

Martinez, L. and Rivera-Acevedo, J.D. (2018) 'Debt Portfolios of the Poor: The Case of Street Vendors in Cali, Colombia', Sustainable Cities and Society 41: 120-5

Mascagni, G.; Prichard, W.; van den Boogaard, V.; Santoro, F. and Orgeira, N. (2020) 'Tracking Covid19's Implications in Africa: Tax Burdens, Tax Attitudes, and the Reach of Tax Relief', paper presented at the Tax Administration Research Centre workshop, 19 June (accessed 19 October 2020)

McCarthy, G.; Smurra, A.; Toth, R.; \& Anonymous Myanmar scholar (2021) 'Precarity, Debt and Taxes: Pandemic Politics and the Fiscal Social Contract in Southeast Asia', paper presented at the Development Studies Association conference

Meagher, K. (2014) 'Disempowerment from Below: Informal Enterprise Networks and the Limits of Political Voice in Nigeria', Oxford Development Studies 42.3: 419-38

Meagher, K. (2007) 'Introduction: Special Issue on “Informal Institutions and Development in Africa', Afrika Spectrum 42.3: 405-18

Meagher, K. and Lindell, I. (2013) 'ASR Forum: Engaging with African Informal Economies: Social Inclusion or Adverse Incorporation? Introduction', African Studies Review 56.3: 57-76

Medina, M. and Schneider, F. (2018) Shadow Economies Around the World: What Did We Learn Over the Last 20 Years?, IMF Working Paper 18/17, Washington DC: International Monetary Fund

Migdal, J.S. (2001) State in Society: Studying How States and Societies Transform and Constitute One Another, Cambridge: Cambridge University Press

Migdal, J.S.; Kohli, A. and Shue, V. (1994) State Power and Social Forces: Domination and Transformation in the Third World, Cambridge: Cambridge University Press

Monye, J. and Abang, O. (2020) Taxing the Informal Sector-Nigeria's Missing Goldmine, Bloomberg Tax blog, 15 October 15 (accessed 25 November 2021)

Moore, M. (2020) What is Wrong With African Tax Administration?, ICTD Working Paper 111, Brighton International Centre for Tax and Development

Mukeredzi, T. (2020) '"Dying of Hunger": Zimbabwe Street Vendors Hit By Coronavirus Clampdown', Reuters, 16 June (accessed 22 September 2020)

Muller, R. (2020) A Message From the President of South African Informal Traders Alliance (SAITA) on the Effects of the Covid-19 Virus to the Informal Business Economy, South African Informal Traders Alliance, 20 March (accessed 19 October 2020)

Naija247news Editorial Team (2021) 'Harness Informal Sector for More Revenue, Igbinedion Varsity DVC Urges Govt', Naija247news, 23 April (accessed 25 November 2021)

Nanda, P. (2002) 'Gender Dimensions of User Fees: Implications for Women's Utilization of Health Care', Reproductive Health Matters, 10.20: 127-34

Narula, R. (2020) 'Policy Opportunities and Challenges From the COVID-19 Pandemic for Economies With Large Informal Sectors', Journal of International Business Policy, 3.3: 302-10 DOI:

10.1057/s42214-020-00059-5 (accessed 25 November 2021)

Noko, K. (2020) In Africa, Social Distancing is a Privilege Few Can Afford, Al Jazeera Opinion, 22 March, (accessed 23 September 2020)

Nyama, G.M.; Mudimu, P. and Walnycki, A. (2020) Working With Informality For More Resilient, Equitable Responses to Covid-19, International Institute for Environment and Development blog, 10 July (accessed 20 September 2020) 
Odinga, P. (2021) Twitter, 27 June (accessed 25 November 2021)

OECD (2021) The Sudden Loss of a Social Buffer: COVID-19 and Informality in Eurasia, Paris: Organisation for Economic Co-operation and Development

OECD (2020a) The COVID-19 crisis in Morocco, Paris: Organisation for Economic Co-operation and Development (accessed 19 October 2020)

OECD (2020b) The Territorial Impact of COVID-19: Managing the Crisis Across Levels of Government, Paris: Organisation for Economic Co-operation and Development (accessed 17 May 2021)

Pande, R.; Schaner, S.; Moore, C.T. and Stacy, E. (2020) A Majority of India's poor Women May Miss COVID-19 PMJDY Cash Transfers, New Haven CT: Yale Economic Growth Center (accessed 23 September 2020)

Patel, S. (2020) Community-Based Organizations Are Key to COVID-19 Response, New York NY: Sanitation and Water For All (accessed 20 September 2020)

Pierson, P. (1994) Dismantling the Welfare State?: Reagan, Thatcher and the Politics of Retrenchment, Cambridge: Cambridge University Press

Post, A.E.; Bronsoler, V. and Salman, L. (2017) 'Hybrid Regimes for Local Public Goods Provision: A Framework for Analysis', Perspectives on Politics 15.4: 952-66

Qiang, C.Z. and Kuo, R. (2020) Supporting Informal Businesses Amid COVID-19 Without Formalization, Private Sector Development blog, 16 December (accessed 25 November 2021)

Raga, S. (2020) Country Fiscal and Monetary Policy Responses to Coronavirus, ODI Supporting Economic Transformation, London: Overseas Development Institute (accessed 19 October 2020)

Rai, S. (2019) 'No Budget for India's Invisible Women Farmers', The Wire, 20 February (accessed 25 November 2021)

Rateng, V. (2020a) 'Improving Kenyans' Access to Cash Transfers for Covid-19 Response', MIT GOV/LAB, August (accessed 25 November 2021)

Rateng, V. (2020b) 'Pandemic Assistance Is Not Meeting Needs of the Most Vulnerable In Nairobi', MIT GOV/LAB, November (accessed 25 November 2021)

Resnick, D. (2019) 'The Politics of Crackdowns on Africa's Informal Vendors', Comparative Politics 52.1: 21-51

Ritchie, H. et al. (2020) Coronavirus Pandemic (COVID-19), Oxford: Our World In Data (accessed 25 November 2021)

Roitman, J. (2007) 'The Right to Tax: Economic Citizenship in the Chad Basin', Citizenship studies 11.2: 187-209

Sabatini, C. (2020) 'To Save the Economy From COVID-19, Protect Informal Workers', World Politics Review, 14 July (accessed 23 September 2020)

Scheepers, E.; Lakhani, I. and Armstrong, K. (2020) Making a Community Action Net (work): Organising in the times of COVID-19, OpenGlobalRights (accessed 25 November 2021)

Schotte, S.; Danquah, M.; Osei, R.D. and Sen, K. (2021) The Labour Market Impact of COVID-19 Lockdowns: Evidence From Ghana, WIDER Working Paper No. 2021/27, Helsinki: UNU-WIDER DOI: 10.35188/UNU-WIDER/2021/965-5 (accessed 25 November 2021)

Schwettmann, J. (2020) Covid-19 and the Informal Economy: Impact and Response Strategies in SubSaharan Africa, Bonn: Friedrich Ebert Stiftung

Sen, P. and Haque, A. (2021) 'Community Leaders and Decentralised Governance: Tales from the SEWA Field', IDS Bulletin 52.1 DOI: 10.19088/1968-2021.106 (accessed 25 November 2021)

SEWA (2020a) COVID and the Impact of the Informal Economy, Research note, Ahmedabad: Self Employed Women's Association

SEWA (2020b) Impact of Coronavirus on the Informal Economy, Research note, Ahmedabad: Self Employed Women's Association

Skocpol, T. (1985) 'Bringing the State Back in: Strategies for Analysis in Current Research', in P. Evans; D. Rueschemeyer and T. Skocpol (eds), Bringing the State Back In, Cambridge: Cambridge University Press

Sultana, F. (2020) 'Embodied Intersectionalities of Urban Citizenship: Water, Infrastructure, and Gender in the Global South', Annals of the American Association of Geographers 110.5: 1407-24 
Sychareun, V. et al. (2016) 'Informal Workers and Access to Healthcare: A Qualitative Study of Facilitators and Barriers to Accessing Healthcare for Beer Promoters in the Lao People's Democratic Republic', International Journal for Equity in Health 15.1: 66

Tendler, J. (2002) 'Small Firms, the Informal Sector and the Devil's Deal', IDS Bulletin 33.3 10.1111/j.1759-5436.2002.tb00035.x (accessed 25 November 2021)

Tsai, L.; Morse, B. and Blair, R. (2020) 'Building Credibility and Cooperation in Low-Trust Settings: Persuasion and Source Accountability in Liberia During the 2014-2015 Ebola Crisis', Comparative Political Studies, 53.10-11: 1582-618

UN (2020) UN Research Roadmap for the COVID-19 Recovery: Leveraging the Power of Science for a More Equitable, Resilient and Sustainable Future, New York NY: United Nations

Vinck, P.; Pham, N.P.; Bindu, K.K.; Bedford, J. and Nilles, E.J. (2019) 'Institutional Trust and Misinformation in the Response to the 2018-19 Ebola Outbreak in North Kivu, DR Congo: A Population-Based Survey', The Lancet Infectious Diseases 19: 529-36

VISET (2020) 'Response to Minister Nyoni's Comments on the Informal Sector Cushioning Fund', Kubatana.net, 4 June (accessed 25 November 2021)

Webster, D. (2020) 'What Happened to the Covid-19 Special Grant?', The Mail \& Guardian, 27 May (accessed 25 November 2021)

WHO and World Bank (2017) Tracking Universal Health Coverage: 2017 Global Monitoring Report, Geneva: World Health Organization

WIEGO (2020a) Informal Workers in the Covid-19 Crisis: A Global Picture of Sudden Impact, Rapid Assessment Note, Manchester: Women in Informal Employment: Globalising and Organising

WIEGO (2020b) Waste Pickers: Essential Service Providers at High Risk, Manchester: Women in Informal Employment: Globalising and Organising (accessed 25 November 2021)

WIEGO (2020c) Informal Worker Demands During COVID-19 Crisis, Manchester: Women in Informal Employment: Globalising and Organising (accessed 25 November 2021)

WIEGO (2020d) Government Responses Covid-19 Crisis, Manchester: Women in Informal Employment: Globalising and Organising

WIEGO (2019) Extending Social Protection to Informal Workers, Briefing Note, Manchester: Women in Informal Employment: Globalising and Organising

Wigmore, R. (2015) Contextualising Ebola Rumours From a Political, Historical and Social Perspective to Understand People's Perceptions of Ebola and the Responses to it, Brighton: University of Sussex (accessed 25 November 2021)

Wilkinson, A. (2020) 'Local Response in Health Emergencies: Key Considerations for Addressing the Covid-19 Pandemic in Informal Urban Settlements', Environment and Urbanization, 32.2: 503-22

Wilkinson, A. and Leach, M. (2015) 'Briefing: Ebola, - Myths, Realities, and Structural Violence', African Affairs, 114.454: 135-48

Woo, J.J. (2020) 'Policy Capacity and Singapore's Response to the COVID-19 Pandemic', Policy and Society 39.3: 345-62

World Bank (2017) The State of Identification Systems in Africa: A Synthesis of Country Assessments, Washington DC: World Bank

Young, A. (1982) 'The Anthropologies of Illness and Sickness', Annual Review of Anthropology 11: 257-85 



\section{(-) institute of development studies}

Delivering world-class research, learning and teaching that transforms the knowledge, action and leadership needed for more equitable and sustainable development globally.

Institute of Development Studies

Library Road

Brighton, BN1 9RE

United Kingdom

+44 (0)1273606261

ids.ac.uk

Charity Registration Number 306371

Charitable Company Number 877338

(C) Institute of Development Studies 2021 